\title{
How permeable are clays and shales?
}

\author{
C. E. Neuzil \\ U. S. Geological Survey, Reston, Virginia
}

\begin{abstract}
The permeability of argillaceous formations, although rarely measured and poorly understood, is commonly a critical parameter in analyses of subsurface flow. Data now available suggest a regular relation between permeability and porosity in clays and shales and permeabilities that, even at large scales, are significantly lower than usually assumed. Permeabilities between $10^{-23}$ and $10^{-17} \mathrm{~m}^{2}$ have been obtained at porosities between 0.1 and 0.4 in both laboratory and regional studies. Although it is clear that transmissive fractures or other heterogeneities control the large-scale hydraulic behavior of certain argillaceous units, the permeability of many others is apparently scale independent. These results have significant implications for understanding fluid transport rates and abnormal pressure generation in basins, and could prove important for waste isolation efforts.
\end{abstract}

\section{Introduction}

Sedimentary units dominated by clay are commonly the least permeable parts of groundwater flow systems and, as such, strongly affect fluid fluxes and flow patterns. The permeability of argillaceous units is therefore a parameter of considerable importance for analyzing groundwater flow in sedimentary environments, with particular importance attaching to the relation between permeability and porosity because of the sediment compaction that accompanies burial. Unfortunately, it is usually infeasible to measure permeability or its variation in argillaceous units and few reliable guidelines exist for estimating it. Specifically, there are few indications of (1) how permeability relates to porosity in these media and (2) how small the permeability of these sediments can be at various scales. Researchers have used estimates based on a few widely cited measurements [e.g., Magara, 1978; Neglia, 1979] or anecdotal values [e.g., Davis and De Wiest, 1966; Lambe and Whitman, 1969; Freeze and Cherry, 1979] and have invoked more or less arbitrary relations between permeability and porosity to account for compaction, practices that add considerable uncertainty to analyses. As a result, clay and shale permeabilities are among the most significant uncertainties in many attempts to quantify subsurface flow.

Data now available provide new insight into this problem and suggest that it is time to reevaluate the treatment of clay and shale permeability in flow simulations. The relatively low permeabilities these data imply at typical porosities indicate that fluid fluxes in some flow systems could be significantly smaller than analyses indicate; elucidation of these fluxes is crucial for understanding phenomena such as abnormal pressure generation, petroleum and ore emplacement, and deformation of sediments, and for guiding intelligent exploitation of the subsurface for purposes such as waste isolation. This paper synthesizes these data and describes their implications.

This paper is not subject to U. S. copyright. Published in 1994 by the American Geophysical Union.

Paper number 93WR02930.

\section{Laboratory Permeability Data}

Until the 1970s, little was known about clay and shale hydraulic properties beyond permeability data obtained as a by-product of consolidation testing. Although attention has been focused on the problem since then, the difficulty of measuring small permeabilities has continued to limit the acquisition of data. As a result, extensive permeability data for these materials do not exist. In addition, a large fraction of the laboratory data that are available are not suited for hydrogeologic applications. Many studies used purified clays or reconstituted sediments, leaving in question the applicability of the results to natural systems. Others failed to report porosity (or void ratio) or gave no indication of how the data were obtained. Only a handfull of laboratory determinations (1) used natural media in an undisturbed state, (2) monitored the reported porosity or equivalent information, and (3) showed evidence that the measurements were made using appropriate methodology and careful technique. Laboratory data I have found that meet these criteria, including data obtained in a recent investigation of the Pierre Shale, are plotted in Figure 1 with background information given in Table 1. With the exception of values for the Pierre Shale, which are presented here for the first time, these data are from published sources.

For completeness, some widely cited data were included in Figure 1 (dashed lines) even though the test protocol was not reported. Test protocol is a critical consideration because measurements of small permeability are quite susceptible to errors. Minutes leaks in the testing apparatus or around the specimen in the test cell and subtle damage or deterioration of the specimen itself are especially difficult to avoid and make measured permeabilities too large; skepticism of relatively large reported values is prudent. In view of this, the significance of regions 11 and 12 is problematical.

In contrast, various considerations indicate that the data shown with solid lines in Figure 1 are reliable. Regions 1, 3, 5 , and 8 were each defined by more than one testing technique (see Table 1). Other data were obtained using robust and well-established mechanical transient (consolidation) techniques (region 6) or with particular care devoted to the test equipment and procedures (regions $2,4,7,9$, and 10 ).

Figure 1 suggests that a log-linear relation between per- 


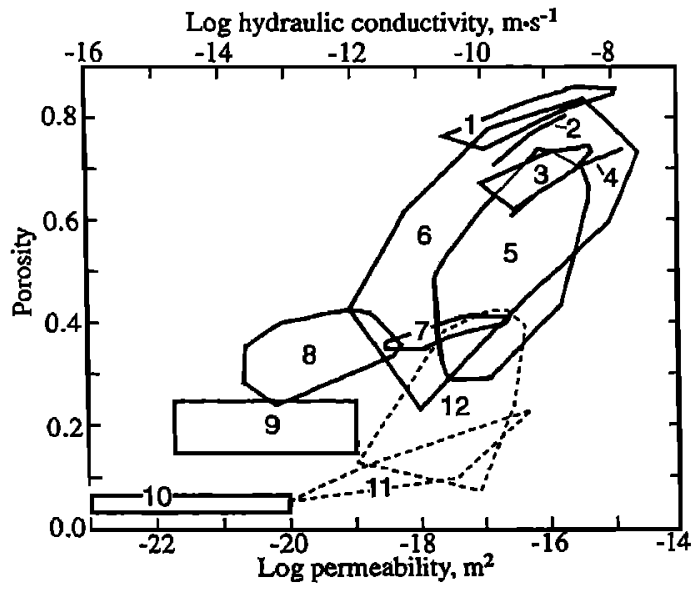

Figure 1. Plot of laboratory-derived permeability versus porosity for a variety of natural argillaceous media. Permeability is shown along the lower horizontal scale: the corresponding hydraulic conductivity to water at room temperature is shown along the upper horizontal scale. The numbers are keyed to Table 1 which provides the source of the data and background information.

meability and porosity exists over an exceptionally wide range of consolidation states; materials ranging from recently deposited marine clays to mildly metamorphosed argillite are represented. Excluding regions 11 and 12, the data fall in a band approximately three orders of magnitude wide that spans porosities exceeding 0.8 to less than 0.1 . Permeability decreases by approximately an order of magnitude with each 0.13 decrease in porosity and ranges over eight orders of magnitude. Regions 11 and 12 depart from the trend, suggesting laboratory-scale permeabilities exceeding $10^{-17} \mathrm{~m}^{2}$ at porosities as low as 0.2 .

The log-linear relation exhibited by the data in Figure 1 is not unexpected for clay-rich media. Several theoretical expressions relate permeability to porosity and pore size; one derived by Kozeny [1927] and modified by Carman [1937], which uses specific surface area as a measure of pore size, appears to provide useful insight in the present context. Although the Kozeny-Carman equation is based on rather restrictive assumptions [Scheidegger, 1974], it predicts permeability of kaolinite clay cakes with reasonable accuracy [Olsen, 1962]. The predicted relation is nearly log linear, with a slope similar to that suggested by Figure 1 .

The broad range in permeability at a given porosity in Figure 1 (even if regions 11 and 12 are discounted) could have multiple causes. First, very small permeabilities are measured at or near the limits of instrumental resolution, which can introduce error. Second, effects of anisotropy may be present in some of the data, with different permeabilities along and across depositional planes. However, the bulk of the variation is attributable to differences in clay microstructure, which Olsen [1962] considered to arise from clustering of clay particles. Experiments with clay cakes [Mitchell et al., 1965] show nearly three orders of magnitude variation in permeability because of microstructural differences. Comparable variation is expectable in nature because of the physically and chemically diverse environments in which argillaceous sediments are deposited.

No data are known to me that indicate clay or shale permeabilities smaller than shown in Figure 1, and there is reason to believe that the minimum measured values are indeed close to the minimum values which can be expected in these media. Grim [1968, p. 464] tabulated values of clay specific surface area. It is reasonable to associate the largest, a theoretical maximum for montmorillonite, with the lowest clay permeabilities. Using this value in the Kozeny-Carman relation yields values within an order of magnitude of the minimum values in Figure 1 . This argues that the data delineate minimum clay and shale permeabilities reasonably well.

\section{Effect of Scale}

Many workers expect an increase in permeability with scale in low-permeability media [Bethke, 1989], leading them to discount laboratory-derived permeabilities as being too low. The scale dependency, usually attributed to fractures or commingling of nonclay sediments, can be difficult to detect directly but is clearly present in some argillaceous units. The Pierre Shale, for example, which has a $10^{-20} \mathrm{~m}^{2}$ permeabil. ity at laboratory scale (region 8 in Figure 1), has a regional permeability of $10^{-16} \mathrm{~m}^{2}$ [Bredehoeft et al., 1983]. Scale dependence also has been detected in lacustrine clay [Rudolph et al., 1991] and clay till [Keller et al., 1988] and is implied in numerous instances when in situ permeability measurements in shales yield relatively large values [Davis, 1988].

Other evidence, however, shows that permeability scale dependence is not ubiquitous in argillaceous media and, when present, may affect flow only at the largest regional scales, and not at intermediate scales. I found several instances where clay and shale permeabilities at subregional to regional scales (kilometers to hundreds of kilometers) are consistent with the trend shown in Figure 1. These largescale permeabilities are plotted in Figure 2 to permit comparison with the laboratory data; Table 2 provides the background information.

The data in Figure 2 were obtained from inverse analyses of a variety of flow systems. Inverse analysis yields estimates of system properties, generally, by numerically simulating flow and adjusting the value of uncertain parameters to obtain computed hydraulic conditions that best match those observed. Inverse methods work reliably for well-posed problems and generally are the only way to evaluate small permeabilities at large scales.

Certain inverse analyses yielded only maximum values: these are indicated by arrows in Figure 2. In the case of regions 6 and 7 , this is due simply to ambiguity inherent in the analyses; a range of permeabilities lower than those indicated give equally good matches to observed conditions. The uncertainty in region 5 exists because inverse analyses sometimes incorporate significant changes in permeability over geologic time. Region 5 is derived from an inverse analysis of geopressures in sediments of the U. S. Gulf Coast by Bethke [1986a]. These sediments may have expelled excess fluid through natural hydrofractures during parts of their history [Engelder, 1993, p. 41; Capuano, 1993]. If permeability indeed varied in time with the presence and absence of transmissive fractures, region 5 represents a time-integrated average of the two conditions. Only the unfractured permeability, which must be smaller, is directly comparable with the laboratory measurements in Figure 1. 
Table 1. Background Information for Laboratory Permeability Data Plotted in Figure 1

\begin{tabular}{|c|c|c|c|c|c|c|c|}
\hline $\begin{array}{l}\text { Region } \\
\text { in } \\
\text { Figure } 1\end{array}$ & $\begin{array}{l}\text { Formation } \\
\text { (Location) }\end{array}$ & $\begin{array}{c}\text { Lithology } \\
\text { (Mineralogy) }\end{array}$ & $\begin{array}{l}\text { Type of Test* } \\
\text { (Permeant) }\end{array}$ & $\begin{array}{l}\text { Orienta- } \\
\text { tion to } \\
\text { Bedding }\end{array}$ & $\begin{array}{l}\text { Number of } \\
\text { Measure- } \\
\text { ments }\end{array}$ & $\begin{array}{c}\text { Effective } \\
\text { Stress, } \\
\text { MPa }\end{array}$ & Source \\
\hline 1 & $\begin{array}{l}\text { bottom deposit } \\
\text { (North Pacific) }\end{array}$ & $\begin{array}{l}\text { bottom mud (illite, } \\
\text { smectite) }\end{array}$ & $\begin{array}{l}\text { mechanical } \\
\text { transient, } \\
\text { steady flow, } \\
\text { and quasi- } \\
\text { steady flow } \\
\text { (seawater) }\end{array}$ & normal (?) & 48 & $0.04-0.4$ & $\begin{array}{l}\text { Silva et al. } \\
\quad[1981]\end{array}$ \\
\hline 2 & $\begin{array}{l}\text { bottom deposit } \\
\text { (North Pacific) }\end{array}$ & $\begin{array}{l}\text { bottom mud (illite, } \\
\text { smectite) }\end{array}$ & $\begin{array}{l}\text { steady flow } \\
\text { (seawater) }\end{array}$ & normal & 19 & & $\begin{array}{l}\text { Morin and Silva } \\
\text { [1984] }\end{array}$ \\
\hline 3 & $\begin{array}{l}\text { bottom deposit } \\
\text { (North Pacific) }\end{array}$ & $\begin{array}{l}\text { bottom mud (illite, } \\
\text { chlorite) }\end{array}$ & $\begin{array}{l}\text { mechanical } \\
\text { transient, and } \\
\text { quasi-steady } \\
\text { flow (seawater) }\end{array}$ & normal (?) & 26 & & $\begin{array}{l}\text { Silva et al. } \\
\quad[1981]\end{array}$ \\
\hline 4 & $\begin{array}{l}\text { bottom deposit } \\
\text { (North Pacific) }\end{array}$ & $\begin{array}{l}\text { bottom mud (illite, } \\
\text { chlorite) }\end{array}$ & $\begin{array}{l}\text { steady flow } \\
\text { (seawater) }\end{array}$ & normal & 22 & & $\begin{array}{l}\text { Morin and Silva } \\
\text { [1984] }\end{array}$ \\
\hline 5 & $\begin{array}{l}\text { Pleistocene to } \\
\text { Recent (Quebec, } \\
\text { Mississippi } \\
\text { Delta, Sweden) }\end{array}$ & $\begin{array}{l}\text { marine and } \\
\text { lacustrine clay }\end{array}$ & $\begin{array}{l}\text { steady flow and } \\
\text { quasi-steady } \\
\text { flow (natural } \\
\text { pore water and } \\
\text { distilled water) }\end{array}$ & normal (?) & $\begin{array}{l}\text { approxi- } \\
\text { mately } \\
600\end{array}$ & $0.04-0.3$ & $\begin{array}{l}\text { Tavenas et al. } \\
\text { [1983] }\end{array}$ \\
\hline 6 & Gulf of Mexico & $\begin{array}{l}\text { unconsolidated } \\
\text { sediment; } \\
\text { varying } \\
\text { proportions of } \\
\text { clay, silt, and } \\
\text { sand }\end{array}$ & $\begin{array}{l}\text { mechanical } \\
\text { transient } \\
\text { (seawater) }\end{array}$ & various & $\begin{array}{l}\text { approxi- } \\
\text { mately } \\
250\end{array}$ & & $\begin{array}{l}\text { Bryant et al. } \\
\text { [1975] }\end{array}$ \\
\hline 7 & $\begin{array}{r}\text { Sutherland Group } \\
\text { (Saskatchewan) }\end{array}$ & $\begin{array}{l}\text { glacial till } \\
\text { (montmorillonite, } \\
\text { illite, kaolinite) }\end{array}$ & $\begin{array}{l}\text { mechanical } \\
\text { transient and } \\
\text { quasi-steady } \\
\text { flow (natural } \\
\text { pore water and } \\
\text { distilled water) }\end{array}$ & normal & 27 & $0.06-2.0$ & $\begin{array}{l}\text { Keller et al. } \\
\text { [1989] }\end{array}$ \\
\hline 8 & $\begin{array}{l}\text { Pierre Shale } \\
\text { (central South } \\
\text { Dakota) }\end{array}$ & $\begin{array}{l}\text { claystone (mixed } \\
\text { layer, } \\
\text { montmorillonite, } \\
\text { illite) }\end{array}$ & $\begin{array}{l}\text { mechanical } \\
\text { transient, } \\
\text { hydraulic } \\
\text { transient, } \\
\text { steady flow } \\
\text { (pore water } \\
\text { duplicate and } \\
\text { distilled water) }\end{array}$ & $\begin{array}{l}\text { normal } \\
\text { and } \\
\text { parallel }\end{array}$ & 85 & $0.1-50$ & $\begin{array}{l}\text { C. } E . \text { Neuzil } \\
\text { (unpublished } \\
\text { data, 1987) }\end{array}$ \\
\hline $9 \dagger$ & $\begin{array}{l}\text { Lower Cretaceous } \\
\text { (Western } \\
\text { Canada) }\end{array}$ & $\begin{array}{l}\text { clayey siltstone, } \\
\text { clayey sandstone }\end{array}$ & $\begin{array}{l}\text { steady flow (3.5 } \\
\text { and } 5.8 \% \\
\text { sodium } \\
\text { chloride) }\end{array}$ & $\begin{array}{l}\text { normal } \\
\text { and } \\
\text { parallel }\end{array}$ & 25 & $0-40$ & $\begin{array}{l}\text { Young et al. } \\
\text { [1964] }\end{array}$ \\
\hline 10 & $\begin{array}{l}\text { Eleana Formation } \\
\text { (Nevada) }\end{array}$ & $\begin{array}{l}\text { argillite (quartz, } \\
\text { illite, chlorite, } \\
\text { kaolinite) }\end{array}$ & $\begin{array}{l}\text { hydraulic } \\
\text { transient }\end{array}$ & various & 23 & $1.1-24.1$ & $\operatorname{Lin}[1978]$ \\
\hline 11 & $\begin{array}{l}\text { (Japan and } \\
\text { Alberta, Canada) }\end{array}$ & $\begin{array}{l}\text { mudstone, sandy } \\
\text { mudstone, } \\
\text { silstone, shale }\end{array}$ & $\begin{array}{l}?\left(8 \text { to } 32 \times 10^{3}\right. \\
\text { mg/L sodium } \\
\text { chloride })\end{array}$ & $?$ & 33 & & Magara [1978] \\
\hline 12 & $\begin{array}{l}\text { Upper Triassic, } \\
\text { Mid-Miocene, } \\
\text { Lower Pliocene } \\
\text { (Italy) }\end{array}$ & clay, shale & $?$ & $?$ & 8 & & Neglia [1979] \\
\hline
\end{tabular}

*Mechanical transient tests include standard consolidation tests and similar procedures involving transient deformation under mechanical loads. Hydraulic transient tests, which include pulse and injection tests, involve varying the hydraulic boundary conditions of the sample and analyzing the transient pressure response. Quasi-steady flow tests are also known as falling head tests. Steady flow tests are "standard" permeability tests. For further discussion of low-permeability testing methodologies, see Neuzil [1986].

†Porosity estimated from description of samples. 


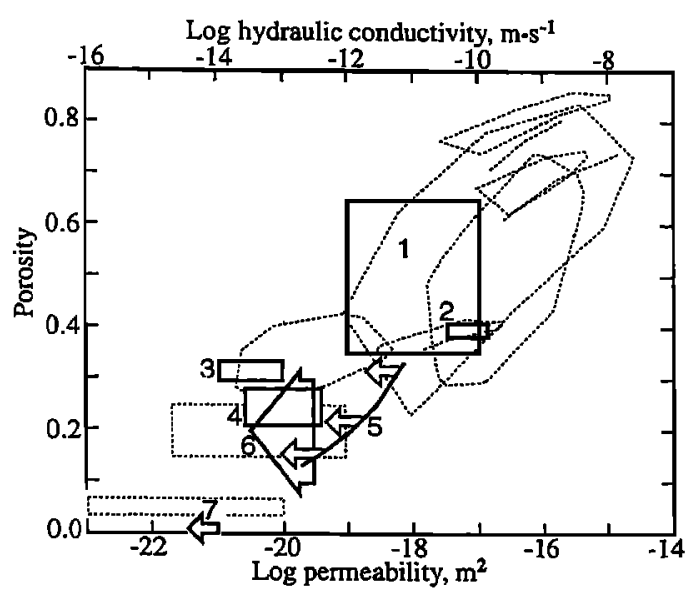

Figure 2. Plot of large-scale permeability versus porosity for a variety of argillaceous units derived from inverse analyses of flow systems. Permeability and hydraulic conductivity scales are as in Figure 1. Dotted lines show data from Figure 1 to facilitate comparison. Arrows indicate results which are upper limits for the permeability. The numbers are keyed to Table 2.

The agreement between laboratory and inverse values in Figures 1 and 2 is striking and provides explicit evidence for scale independence of permeability in argillaceous media. Significant fracture permeability apparently is absent in these materials, which include a highly lithified, low porosity unit that one would expect to be prone to fracturing (region 7 in Figure 2). This result extends earlier evidence [Brace,
1980; Davis, 1988] which implied that the permeability scale effect in argillaceous rocks could be small.

Only two formations are represented in both Figures 1 and 2: the Sutherland Till and the Pierre Shale. Keller et al. [1989] found that laboratory tests and inverse estimates yielded comparable values of permeability for the Sutherland Till (compare region 7 in Figure 1 and region 2 in Figure 2). However, the inverse estimates apply to relatively small volumes having maximum dimensions of tens of meters. In the case of the Pierre Shale, as already noted, basinwide analysis [Bredehoeft et al., 1983] yielded a relatively large permeability of $10^{-16} \mathrm{~m}^{2}\left(10^{-9} \mathrm{~ms}^{-1}\right)$; this result applies to an area with dimensions of hundreds of kilometers. A more recent study of a few $\mathrm{km}^{2}$ portion of the basin [Neuzil, 1993] shows, however, that a much smaller value (region 3 , Figure 2) applies there. Permeability scale dependence exists, but apparently only at greater than kilometer scale. This points to the presence of transmissive fractures that are separated by distances of kilometers or more. Note also that many of the laboratory values for the Pierre Shale are higher than the inverse estimate (compare region 8, Figure 1 and region 3 , Figure 2), probably because of deterioration of the core samples before laboratory testing [Neuzil, 1993].

\section{Implications}

The increasing speed of digital computers has stimulated efforts to analyze subsurface fluid flow using numerical simulation. For example, significant effort has been devoted to analyzing paleoflow in sedimentary basins because of its relevance to economic minerals and waste disposal. Recently, we have seen studies that have simulated paleoflow

Table 2. Background Information for Inverse Permeability Estimates Plotted in Figure 2

\begin{tabular}{|c|c|c|c|c|c|c|}
\hline $\begin{array}{l}\text { Region } \\
\text { in } \\
\text { Figure } 2\end{array}$ & $\begin{array}{l}\text { Formation } \\
\text { (Location) }\end{array}$ & $\begin{array}{c}\text { Lithology } \\
\text { (Mineralogy) }\end{array}$ & $\begin{array}{l}\text { Type of } \\
\text { Analysis }\end{array}$ & $\begin{array}{l}\text { Orientation } \\
\text { to Bedding }\end{array}$ & $\begin{array}{l}\text { Vertical and } \\
\text { Horizontal } \\
\text { Dimensions }\end{array}$ & Source \\
\hline 1 & $\begin{array}{l}\text { (Barbados } \\
\text { Accretionary } \\
\text { Ridge complex) }\end{array}$ & $\begin{array}{l}\text { clay, calcareous } \\
\text { mudstone }\end{array}$ & transient flow & various & 1 and $15 \mathrm{~km}$ & $\begin{array}{l}\text { Screaton et al. } \\
\quad[1990]\end{array}$ \\
\hline 2 & $\begin{array}{l}\text { Sutherland Group } \\
\text { (Saskatchewan) }\end{array}$ & $\begin{array}{l}\text { glacial till } \\
\text { (montmorillonite, } \\
\text { kaolinite) }\end{array}$ & transient flow & $\begin{array}{c}\text { normal and } \\
\text { parallel }\end{array}$ & $<50$ and $\sim 10 \mathrm{~m}$ & $\begin{array}{l}\text { Keller et al. } \\
\text { [1989] }\end{array}$ \\
\hline 3 & $\begin{array}{l}\text { Pierre Shale } \\
\text { (Central South } \\
\text { Dakota) }\end{array}$ & $\begin{array}{l}\text { claystone (mixed } \\
\text { layer, } \\
\text { montmorillonite, } \\
\text { illite) }\end{array}$ & transient flow & normal & 0.3 and $>1 \mathrm{~km}$ & Neuzil [1993] \\
\hline $4^{*}$ & $\begin{array}{l}\text { Colorado Group } \\
\text { and Upper } \\
\text { Manville Shales } \\
\text { (Alberta) }\end{array}$ & claystone, shale & transient flow & normal & 0.5 and $>100 \mathrm{~km}$ & $\begin{array}{l}\text { Corbet and } \\
\text { Bethke [1992] }\end{array}$ \\
\hline 5 & Gulf of Mexico & clay, shale & transient flow & normal & 10 and $>300 \mathrm{~km}$ & Bethke [1986a] \\
\hline $6^{*}$ & $\begin{array}{l}\text { Pierre, Carlile, } \\
\text { Graneros } \\
\text { Shales (Denver } \\
\text { Basin) }\end{array}$ & claystone and shale & steady state flow & normal & 3 and $800 \mathrm{~km}$ & $\begin{array}{l}\text { Belitz and } \\
\text { Bredehoeft } \\
\text { [1988] }\end{array}$ \\
\hline 7 & (Siberia) & $\begin{array}{l}\text { "argillaceous } \\
\text { rock" }\end{array}$ & transient flow & normal (?) & & $\begin{array}{l}\text { Nesterov and } \\
\text { Ushatinskii as } \\
\text { reported by } \\
\text { Brace }[1980]\end{array}$ \\
\hline
\end{tabular}

*Porosity range estimated from depth and thickness of sediments (T. F. Corbet, Jr., Sandia National Laboratory, personal communication, 1993, and K. Belitz, Dartmouth College, personal communication, 1993). 
regimes driven by compaction [Bethke, 1985; Harrison and Summa, 1991], tectonic deformation [Deming et al., 1990: Ge and Garven, 1992], topographic relief [Garven, 1985, 1989; Bethke, 1986b, Senger and Fogg, 1987], and erosion [Senger et al., 1987]. Such analyses are inherently uncertain because the system hydraulic properties in the geologic past must be estimated. Permeabilities or ranges of permeability assumed for argillaceous units, as in the studies cited above, are commonly between $10^{-19}$ to $10^{-16} \mathrm{~m}^{2}$ (hydraulic conductivity of $10^{-12}$ to $10^{-9} \mathrm{~ms}^{-1}$ ) for porosities less than 0.4 . Figures 1 and 2 suggest that argillaceous formations can be much less permeable, with values in the range of $10^{-23}$ to $10^{-17} \mathrm{~m}^{2}\left(10^{-16}\right.$ to $\left.10^{-10} \mathrm{~ms}^{-1}\right)$ for the same porosity range. of course, argillaceous units mapped at large scales frequently incorporate relatively permeable subunits and their permeability can be correspondingly high. Nevertheless, as Figure 2 shows, they apparently can be dominated by their low-permeability components. This probably is most often true for flow normal to stratification, which is controlled by the least permeable horizons.

Adoption of the relatively low permeabilities indicated by Figures 1 and 2 would result in reinterpretation of some flow regimes. In a topographically driven flow system mediated by leakage through a shale, simulations using lowered shale permeabilities at basin scale (hundreds of kilometers) would indicate reduced rates of fluid transport throughout the system. Phenomena associated with advective fluid transport, such as petroleum accumulation and emplacement of ores, would require more time or different mechanisms than originally indicated.

In geologically active areas, such as the foreland basin undergoing tectonic compression analyzed by Ge and Garven [1992], the permeability of argillaceous sediments can determine the degree to which flow is affected by the geologic activity. Rock deformation caused by tectonic compression, for example, tends to perturb fluid pressures; a small permeability causes the perturbations to persist and accumulate to significant levels. A variety of geological processes can similarly affect fluid pressure [Neuzil, 1986]. Because the data presented here suggest permeabilities lower than usually assumed, they also imply that abnormal pressures caused by such geologic forcing may occur more readily than presently supposed. This is consistent with the widespread occurrence of features such as thrust faulting and multiple generation fracturing, which are thought to require high fluid pressures [Engelder, 1990].

The permeability data presented here also have implications for subsurface waste isolation, In a broad sense, the data can aid characterization of fluid fluxes, which is necessary for assessing the risk of advecting toxic waste from a repository to the biosphere. Figures 1 and 2, however, have a direct implication for repository siting. The absence of secondary permeability in some argillaceous formations may make them viable repository venues.

I have skirted questions about the applicability of Darcy's law in argillaceous media. Uncertainty attaches to flow at moderate to low hydraulic gradients in clayey materials; in particular, various investigators have described so-called threshold gradients below which clay behaves as if it is impermeable [Neuzil, 1986]. Laboratory tests use hydraulic gradients that are too large to allow definitive tests of such non-Darcian flow models. However, the agreement between laboratory and inverse permeability estimates evident in
Figures 1 and 2, with the latter based on flow at moderate to low gradients, argues against the existence of any significant non-Darcian effects in the media represented.

\section{Conclusions}

Much remains to be learned about the hydraulic properties of clays and shales. For example, we are unable to predict how and where heterogeneity (due to depositional architecture or fracturing) will affect large-scale permeability in these media. For the present, when explicit data are not available, flow analyses must consider a range of permeability values for argillaceous units. Unless there is evidence to the contrary, permeability values as low as those indicated in Figures 1 and 2 should be considered possible even at regional scales. Values lower than shown, however, probably need not be considered. Because laboratory permeabilities at similar porosities can vary by a factor of $10^{3}$, stratification in argillaceous sediments may create permeability anisotropy of a similar magnitude. These conclusions probably apply to a wide variety of clayey deposits, inasmuch as clayey siltstone and even clayey sandstone are represented in the data.

Acknowledgments. I wish to thank Grant Garven, Ward Sanford, Dave Rudolph, Craig Bethke, and two anonymous reviewers for their helpful comments on this paper.

\section{References}

Belitz, K., and J. D. Bredehoeft, Hydrodynamics of Denver Basin: Explanation of subnormal fiuid pressure, Am. Assoc. Petl. Geol. Bull., 72(11), 1334-1359, 1988.

Bethke, C. M., A numerical model of compaction-driven groundwater flow and heat transfer and its application to the paleohydrology of intracratonic sedimentary basins, J. Geophys. Res., 90(B8), 6817-6828, 1985.

Bethke, C. M., Inverse hydrologic analysis of the distribution and origin of Gulf Coast-type geopressured zones, J. Geophys. Res., 91(B6), 6535-6545, 1986a.

Bethke, C. M., Hydrologic constraints on the genesis of the Upper Mississippi Valley Mineral District from Illinois Basin brines, Econ. Geol., 81(2), 233-249, 1986b.

Bethke, C. M., Modeling subsurface flow in sedimentary basins, Geol. Rundsch., 78(1), 129-154, 1989.

Brace, W. F., Permeability of crystalline and argillaceous rocks, Int. J. Rock Mech. Min. Sci., I7(5), 241-245, 1980.

Bredehoeft, J. D., C. E. Neuzil, and P. C. D. Milly, Regional flow in the Dakota Aquifer: A study of the role of confining layers, U. S. Geol. Surv. Water Supply Pap., 2237, 45 pp., 1983.

Bryant, W. R., W. Hottman, and P. Trabant, Permeability of unconsolidated and consolidated marine sediments, Gulf of Mexico, Mar. Geotechnolo., I(1), 1-14, 1975.

Capuano, R. M., Evidence of fluid flow in microfractures in geopressured shales, Am. Asso. Petl. Geol. Bull., 77(8), 1303-1304, 1993.

Carman, P. C., Fluid flow through granular beds, Trans. Inst. Chem. Eng., 15, 150-166, 1937.

Corbet, T. F., and C. M. Bethke, Disequilibrium fluid pressures and groundwater flow in the western Canada sedimentary basin, $J$. Geophys. Res., 97(B5), 7203-7217, 1992.

Davis, S. N., Sandstones and shales, in The Geology of North America, vol. O-2, Hydrogeology, edited by W. Back, J. S. Rosenshein, and P. R. Seaber, pp. 323-332, Geological Society of America, Boulder, Colo., 1988.

Davis, S. N., and R. J. M. De Weist, Hydrogeology, 463 pp., John Wiley, New York, 1966.

Deming, D., J. A. Nunn, and D. G. Evans, Thermal effects of compaction-driven groundwater flow from overthrust belts, $J$. Geophys. Res., 95(B5), 6669-6683, 1990.

Engelder, T., Snoluchowski's dilemma revisited: A note on the 
fluid pressure history of the central Appalachian fold-thrust belt in The Role of Fluids in Crustal Processes, edited by J. D. Bredehoeft and D. L. Norton, pp. 140-147, National Academy Press, Washington, D.C., 1990.

Engelder, T., Stress Regimes in the Lithosphere, 457 pp., Princeton University Press, Princeton, N. J., 1993.

Freeze, R. A., and J. A. Cherry, Groundwater, 604 pp., PrenticeHall, Englewood Cliffs, N. J., 1979.

Garven, G., The role of regional fluid flow in the genesis of the Pine Point deposit, Western Canada sedimentary basin, Econ. Geol., $80(2), 307-324,1985$

Garven, G., A hydrogeologic model for the formation of the giant oil sands deposits of the Western Canada sedimentary basin, Am. J. Sci., 289, 105-166, 1989.

Ge, S., and G. Garven, Hydromechanical modeling of tectonically driven groundwater flow with application to the Arkoma Foreland Basin, J. Geophys. Res., 97(B6), 9119-9144, 1992.

Grim, R. E., Clay Mineralogy, 596 pp., McGraw-Hill, New York, 1968.

Harrison, W. J., and L. L. Summa, Paleohydrology of the Gulf of Mexico Basin, Am. Jr. Sci., 291, 109-176, 1991.

Keller, C. K., G. van der Kamp, and J. A. Cherry, Hydrogeology of two Saskatchewan tills, I, Fractures, bulk permeability, and spatial variability of downward flow, J. Hydrol., 101(1-4), 97-121, 1988.

Keller, C. K., G. van der Kamp, and J. A. Cherry, A multiscale study of the permeability of a thick clayey till, Water Resour. Res., 25(11), 2299-2317, 1989.

Kozeny, J., Uber kapillare Leitung des Wassers im Boden, Sitzungsber. Oesterr. Akad. Wiss. Math. Naturwiss Kl. Abt. $2 a$, 136(5\&6), 271-307, 1927.

Lambe, T. W., and R. V. Whitman, Soil Mechanics, 553 pp., John Wiley, New York, 1969.

Lin, W., Measuring the permeability of Eleana Argillite from area 17, Nevada Test Site, using the transient method, Rep. UCRL52604, 11 pp., Lawrence Livermore Lab., Livermore, Calif., 1978.

Magara, K., Compaction and Fluid Migration, 319 pp., Elsevier, New York, 1978.

Mitchell, J. K., D. R. Hooper, and R. G. Campanella, Permeability of compacted clay, J. Soil Mech. Found. Div. Am. Soc. Civ. Eng., 91(SM4), 41-65, 1965.

Morin, R., and A. J. Silva, The effects of high pressure and high temperature on some physical properties of ocean sediments, $J$. Geophys. Res., 89(B1), 511-526, 1984.

Neglia, S., Migration of fluids in sedimentary basins, Am. Assoc. Pet. Geol. Bull., 63(4), 573-597, 1979.

Neuzil, C. E., Groundwater flow in low-permeability environments, Water Resour. Res., 22(8), 1163-1195, 1986.

Neuzil, C. E., Low fluid pressure within the Pierre Shale: A transient response to erosion, Water Resour. Res., 29(7), 2007$2020,1993$.

Olsen, H. W., Hydraulic flow through saturated clays, Clays Clay Miner., 9, 131-161, 1962.

Rudolph, D. L., J. A. Cherry, and R. N. Farvolden, Groundwater flow and solute transport in fractured lacustrine clay near Mexico City, Water Resour. Res., 27(9), 2187-2201, 1991.

Scheidegger, A. E., The Physics of Flow Through Porous Media, 3rd ed., 353 pp., University of Toronto Press, Toronto, Ont. 1974.

Screaton, E. J., D. R. Wuthrich, and S. J. Dreiss, Permeabilities, fluid pressures, and flow rates in the Barbados ridge complex, $J$. Geophys. Res., 95(B6), 8997-9007, 1990.

Senger, R. K., and G. E. Fogg, Regional underpressuring in deep brine aquifers, Palo Duro Basin, Texas, 1, Effects of hydrostratigraphy and topography, Water Resour. Res., 23(8), 1481-1493, 1987.

Senger, R. K., C. W. Kreitler, and G. E. Fogg, Regional underpressuring in deep brine aquifers, Palo Duro Basin, Texas, 2, The effect of Cenozoic basin development, Water Resour. Res., 23(8), 1494-1504, 1987.

Silva, A. J., J. R. Hetherman, and D. 1. Calnan, Low-gradient permeability testing of fine-grained marine sediments, ASTM Special Technical Publication 746, edited by T. F. Zimmie and C. O. Riggs, pp. 121-136, American Society for Testing and Materials, Philadelphia, Penn., 1981.

Tavenas, F., P. Jean, P. Leblond, and S. Leroueil, The permeability of natural soft clays, II, Permeability characteristics, Can. Geotech. J., 20(4), 645-660, 1983.

Young, A., P. F. Low, and A. S. McLatchie, Permeability studies of argillaceous rocks, J. Geophys. Res., 69(20), 4237-4245, 1964.

C. E. Neuzil, U. S. Geological Survey, 431 National Center, MS 431, Reston, VA 22092.

(Received April 30, 1993; revised October 2, 1993; accepted October 19, 1993.) 